\title{
Pakistan: Indus Basin Water Strategy - Past, Present and
}

\section{Future}

\section{Shahid Amjad Chaudhry*}

\begin{abstract}
This paper looks at the Indus Basin Water Strategy for Pakistan. It begins with a historical overview of the Indus Basin Irrigation System (IBIS), the Indus Basin Replacement Works (1960-1980) and the Indus Basin Salinity Control Efforts (1960-2000). The paper then looks at the IBIS irrigation and salinity control investments that have taken place over the last decade (2000-2010). The paper goes on to look at the present situation of the IBIS as well as discuss an IBIS strategy for the next decade. Finally, the paper discusses supply side and demand management strategies for IBIS. Overall, the paper concludes that Pakistan should focus on (1) Creating Additional Surface Storage, (2) Preserving surface water (particularly through lining canals), (3) Controlling Groundwater and controlling salinity (by discouraging excessive tube-well use), (4) Encouraging general efficiency of irrigation water use (through improved land management techniques), (5) Enhancing yields through improved farming practices, and (6) Fully meeting the environmental concerns of the Indus Delta, river systems and wetlands.
\end{abstract}

Keywords: Indus Basin, water, strategy, irrigation, Pakistan.

JEL Classification: Q15, Q25.

\section{Introduction}

Pakistan's Indus Basin Irrigation System (IBIS) is the strong heart of the country's economy. Its creation is a tribute to the British irrigation engineers who created the original system (1847-1947) that Pakistan inherited in 1947 and to the Pakistani irrigation engineers and institutions (particularly the Water and Power Development Authority [WAPDA] and the provincial irrigation departments) who have spent the last 60 years adding new dams and barrages, building new link and branch canals, and modernizing and

* Rector, Lahore School of Economics, and Former Deputy Chairman, Planning Commission, Government of Pakistan. 
maintaining the world's most complex and extensive irrigation system. From the 1950s onward, the IBIS has also been the product of the generosity and intellectual input of a host of international experts and international institutions, particularly the World Bank. This paper starts with a review of what has been accomplished in order to put the IBIS into perspective and illustrate the magnitude of the effort put into building the present system. The paper's aim is to sketch the task ahead and develop a coherent national strategy for the preservation of the IBIS for the future.

\section{The Indus Basin: The First Decade 1947-1957}

The Revelle Report ${ }^{1}$ commissioned by President Kennedy following a request from President Ayub Khan in 1961 provides a fascinating look at Pakistan in this period. It paints a West Pakistan of 43 million people, malnourished and desperately poor with an average income of less than 20 cents/day, and an average life span of less than 45 years, with a $10 \%$ rate of literacy- "industrious, frugal, progressive ... their watch word: 'our sons will have it better'" (Revelle, et a1. 1964: 35). Pakistan at this time was overwhelmingly rural. There was a magnificent canal irrigation system based on the River Indus and its five tributaries (the Jhelum, Chenab, Ravi, Sutlej, and Beas), but it was plagued by its seasonal nature and lack of surface storage (nearly half the flows went to sea unused in the summer, with less than 2 feet/acre left for the irrigated land). Thirty percent of the cultivated land of 35 million acres was affected by water logging and salinity. Most of all, the report said: "In West Pakistan we have the wasteful paradox of a great and modern irrigation system pouring its waters onto lands cultivated as they were in the days of Abraham, Isaac and Jacob" (Revelle, et al. 1964: 65). The report also presented estimates of irrigation requirements in West Pakistan for various crops: wheat 16"/acre, cotton 28-37"/acre, sugarcane 6480"/acre, and rice 35"/acre (Revelle, et a1. 1964: 213). The irrigation system during the 1950s (largely inherited pre-1947) consisted of 10 barrages (Thal, Jinnah, Taunsa, Guddu, Sukkur, Kotri, Trimmu, Dipalpur, Suleimanke, Islam, and Panjnad) and 35,000 miles of canals. Indus Basin inflow was 167 million acre feet (MAF) (average 1921-46 and 1952-57) of which 32.7 MAF (average 1921-46) was from the Ravi (6.4 MAF), and Sutlej/Beas (26.3 MAF) (Revelle, et a1. 1964: 69). India had started depriving Pakistan of water from the three eastern rivers, i.e., the Ravi, Sutlej, and Beas from March 1948. This 1ed Pakistan to negotiate and sign the Indus Water Accord (IWA) in 1960, with

\footnotetext{
${ }^{1}$ Report on Land and Water Development in the Indus Plain, Revelle, Hoffman, Falcon et al. The White House 1964.
} 
India giving Pakistan the rights to the Indus, Jhelum, and Chenab, and India the rights to the Ravi, Sutlej, and Beas in perpetuity. ${ }^{2}$

\section{The Indus Basin Replacement Works (1960-80) and Salinity Control (1960-2000)}

Subsequent to the Indus Water Treaty negotiated with India with the help of the World Bank, a massive irrigation river link canal water scheme comprising two large storages, several barrages, and a number of major link canals was undertaken by the newly created WAPDA (under a World Bank umbrella) to transfer $20 \mathrm{MAF}$ of water from the Indus and Jhelum to the Ravi and Sutlej irrigation commands within Pakistan to substitute for the $30 \mathrm{MAF}$ given to India (the Beas merges with the Sutlej in India). ${ }^{3}$ Two major dams were constructed, one at Mangla (6 MAF) on the Jhelum, and the second at Tarbela (9 MAF) on the Indus to provide water to the new link canals in the lean winter (kharif) season. Thus, by 1980 Pakistan had two major dams (Mangla and Tarbela), one medium barragecum-dam at Chashma (0.8 MAF), 19 barrages, 12 link canals, 43 canal commands covering 90,000 chaks through about 40,000 miles of branch canals, main canals, and distributaries; and water courses, field channels, and field ditches running approximately another 1 million miles. ${ }^{4}$ The total replacement cost of the infrastructure is currently estimated at more than $\$ 60$ billion,' and of these, the two major dams (Tarbela and Mangla), a syphon-cum-barrage (Mailsi), five barrages (Chashma, Rasul, Qadirabad, Marala, and Sidnai), and eight major link canals were built under the Indus Basin Replacement Works. ${ }^{6}$ A large number of existing canals and their associated irrigation infrastructure were also remodeled to accommodate the increased requirements of the replacement system. The World Bank's assistance was invaluable, both on the technical and financial side, as was its role as guarantor of the Indus Basin Water Treaty and its assumption of responsibility for the completion of the replacement works. The role of WAPDA in designing and executing the program was as important. This combination, together with Pakistani and international funding, enabled the entire Indus Basin Replacement Works to be completed by the early 1970s.

2 “Analysis of Water Accords," Kazi A. in Politics of Managing Water, Oxford University Press 1999 pp.164-169.

${ }^{3}$ Study of the Water Resources of West Pakistan Vol. II, The Lieftinck Report, IBRD 1967 Annex Map.

4 "Issues in Water Policy Reforms," by Mahmood Ahmed, in The Politics of Managing Water, Edited by Bengali K, Oxford University Press 1999; pp 73-76.

${ }^{5}$ Pakistan Water Economy Running Dry IBRD 2005, p 58.

6 "Issues in Water Policy Reforms," by Mahmood Ahmed, in The Politics of Managing Water, Edited by Bengali K, Oxford University Press 1999; pp 73-76. 


\section{Salinity Control (1960-2000).}

While covering the entire agriculture sector, Revelle, et a1. (1964) also focused on salinity control, this having been President Ayub Khan's original request to President Kennedy during the former's visit to the United States in 1961. At the time of independence (1947), Pakistan's Indus Basin was already affected by water logging and salinity as a result of the massive irrigation canal system having been established on a flat plain with no natural drainage. By the end of the 1950 s, almost $30 \%$ of the entire Indus Basin command was badly affected while another $30 \%$ had high water tables and indicated the adverse effect of salinity. The Revelle Report was bold in its recommendations. It recommended covering $70-80 \%$ of the Indus Basin irrigated land or 25 to 30 million acres of the total cultivated area of 35 million acres by dividing it into 25 to 30 project areas of roughly 40 miles square $(1,600$ square miles) or approximately 1 million acres, with each new project starting every year after a two-year preparatory period and extending over two decades. ${ }^{7}$ The projects were to focus on the provision of large public sector tube wells to lower the water table and, as an additional benefit, to provide more irrigation water. As a result of this White House study, the World Bank in collaboration with the Government of Pakistan and at the urging of the US Government financed over 40 years (from the 1960 s to the end of the 1990s) a large number of salinity control projects costing more than $\$ 1$ billion. This effort started with Salinity Control and Reclamation Programs (SCARPs) in the 1960s, focusing on vertical drainage through large capacity public sector tube-wells and vertical drains. These projects were executed by WAPDA over three decades and covered all major salinity-affected areas, proving a great success. However, by the 1970s, it was evident that the private sector had started using Pakistan-made small private tube wells essentially for groundwater extraction but with the same ground table lowering effect; as a result, the SCARPs had become largely superfluous. ${ }^{8}$ However, by this time 16,700 large capacity public tube-wells had been installed: a substantial number still exist today and provide 7.81 MAF of water to the system.,11 The Government of Pakistan and the World Bank then shifted their strategy and focused on overall drainage management throughout the Indus Basin including through tile drainage. An innovative salinity drainage project, the Left Bank Outfall Drain (LBOD), was also executed in this period in Sindh to transfer saline water directly to the sea on the left bank of the Indus River. A small Right Bank Outfall Drain Project (RBOD I) was also undertaken to channel saline water from

\footnotetext{
${ }^{7}$ Lieftinck, op.cit. pp. 130-131.

${ }^{8}$ Pakistan Water Economy Running Dry. World Bank 2005 opcit. pp. 94-99.

${ }^{9}$ Pakistan Agricultural Statistics - 2009, pp. 64,
} 
upper Sindh and Balochistan to the Indus River near Manchar Lake in Sindh, but due to general opposition in Sindh to adding saline water to the Indus River, ended up terminating at Manchar Lake with severely adverse consequences for the lake. This problem is now being a resolved through RBOD II (discussed later). Today, as a result of these World Bank-financed projects and also as a result of the more than 0.8 million private tube-wells providing more than half of Pakistan's total water requirements ${ }^{10}$ (or about 50 MAF), Pakistan's salinity problem is confined to about 5 million acres of irrigated areas of which $30 \%$ lies in the Punjab and the balance in Sindh. In addition, another 2.44 million acres is waterlogged. ${ }^{11}$ This is a vast improvement from the 1950s when salinity had rendered 10-12 million acres of land unusable and was, to some extent, estimated to affect a total of about 25-30 million acres by Revelle, et a1. (1964).

\section{IBIS Investments in the Last Decade 2000-2010}

\section{Irrigation Investments 2000-2010.}

The last decade has seen the initiation and completion of a number of important projects relating to the Indus Basin, financed in large part by the Government of Pakistan itself. These include: (i) the Mangla Dam Raising Project 2003-2010 (raising the Mangla Dam 30 feet and thereby adding an additional 2.9 MAF to its existing capacity of $6 \mathrm{MAF}$ at an original cost of Rs 63 billion); (ii) the Greater Thal Canal Project in Punjab 2002-2010 (creating a new culturable command area [CCA] of 1.5 million acres at a cost of Rs30 billion); (iii) the Kachhi Canal Project for Balochistan, covering Dera Bugti, Naseerabad, and Jhal Magsi 2002-2012 (creating a new CCA of 0.71 million acres at a cost of Rs 31 billion); and (iv) the Rainee Canal Project for Sindh, covering Ghotki, Khairpur, and Sukkur 2002-2012 (creating a new CCA of 0.41 million acres at a cost of Rs 19 billion). ${ }^{12}$ In addition, a major effort was made for the first time in Pakistan to start the rehabilitation of the Indus Water Irrigation System by starting the Irrigation System Rehabilitation Project in Sindh in 2002 at a cost of Rs 12 billion. ${ }^{13}$ This project is nearly complete. All these projects were financed almost entirely by the Government of Pakistan and executed exclusively by WAPDA, except for the Sindh Irrigation Rehabilitation Project which is being executed by the Government of Sindh and marks for the first time a separation between Government of Pakistan and

\footnotetext{
10 "Managing Salinity and Water logging in Pakistan": Qureshi A.S. et al. Agriculture Water Management Journal, Volume 95, 2008, pp. 2.

${ }^{11}$ Ibid. pp. 3.

${ }^{12}$ Water Resources and Hydro-power Development Vision 2025. WAPDA 2004.

${ }^{13}$ Annual Review (2001-2) of the Ten Year Perspective Plan 2001-11 and Three Year Development Program 2002-05. Planning Commission 2002, pp. 306.
} 
World Bank projects. As far as the water sector has been concerned in this period, the World Bank has focused almost entirely on institutional development. $^{14}$ Except for a barrage rehabilitation project, World Bank irrigation-related projects were only for "institutional development" and represented a continuation of its boycott of irrigation infrastructure investment in Pakistan from 1997 onward and its policy decision to focus on institutional issues and, in the longer term, seek the privatization of Pakistan's irrigation sector. This was similar to its earlier decision not to lend for energy development since 1987 and focus on the privatization of the energy sector. In 1987, the World Bank also stopped the Government through legal covenants from building thermal power plants in the public sector, which is largely responsible for the energy crisis facing Pakistan today. However, there are reports that the World Bank may finance new public sector hydro-electric projects and continue the rehabilitation of barrages.

\section{Salinity Control Investment 2000-2010.}

On the salinity drainage control front, a large second RBOD project in Sind was undertaken to channel away saline water from Sindh and Balochistan that was previously being disposed of into Manchar Lake (discussed earlier). This project (RBOD II) aims at extending RBOD I from near Manchar to the Arabian Sea, together with additional saline water collected along its length. It is intended both to revive Manchar Lake and also to remove saline water along the entire right bank of the Indus in Sindh. With a capacity of 4,000 cusecs, the project was started in 2002 at a total cost of Rs 10 billion and is nearing completion. ${ }^{15}$ This project was financed entirely by the Government of Pakistan and is being executed by the Government of Sindh.

\section{The Present (2008-10) Situation of the IBIS}

Today, the IBIS is relatively stable as a result of investments in the Indus Basin Replacement Works, additional storages built at Mangla and Tarbela, and the large-scale reduction and, in many areas, elimination of water logging and salinity earlier through SCARPs and subsequently through private sector tube-wells. Private sector tube-wells and SCARP tube-wells add an additional $50 \mathrm{MAF}$ to the system (mostly in the Punjab) and lower the water table, thereby reducing salinity in substantial part in Punjab and to some extent in Sindh. Saline water is also removed by the LBOD and RBOD in Sindh. Table-1 below summarizes the current situation with

\footnotetext{
${ }^{14}$ Pakistan Economy Running Dry. World Bank 2005 pp. 113-115.

${ }^{15}$ Annual Review (2001-2) of the Ten Year Perspective Plan. Op.cit. pp. 306.
} 
regard to surface water use and availability. The current situation with regard to water logging and salinity and surface water use is discussed later.

Table-1: IBIS - Canal Withdrawals (Million Acre Feet)

\begin{tabular}{|c|c|c|c|c|c|c|}
\hline \multirow[b]{2}{*}{ NWFP } & $\begin{array}{l}\text { Average } \\
1952-57^{1}\end{array}$ & $\begin{array}{l}\text { Drought } \\
\text { Year } \\
2001-2^{2}\end{array}$ & $\begin{array}{l}5 \text { Years } \\
\text { Avg. } \\
2001 / 2- \\
2004 / 5^{2} \\
\end{array}$ & $2007-8^{2}$ & \multicolumn{2}{|c|}{$\begin{array}{c}1990 \text { Inter } \\
\text { Provincial } \\
\text { Accord Indus } \\
\text { Basin }^{3} \\
\end{array}$} \\
\hline & $2.8 \quad(4 \%)$ & $4.6 \quad(6 \%)$ & $4.6 \quad(5 \%)$ & $5.1 \quad(5 \%)$ & 8.78 & (7\%) \\
\hline Punjab & $40.4(55 \%)$ & $40.4(51 \%)$ & $46.6(52 \%)$ & $55.4(53 \%)$ & 55.94 & $(48 \%)$ \\
\hline $\begin{array}{l}\text { Sind \& } \\
\text { Baluchistan }\end{array}$ & $30.4(41 \%)$ & $34.6(43 \%)$ & $38.8 \quad(43 \%)$ & $44.0(42 \%)$ & 52.63 & $(45 \%)$ \\
\hline \multirow[t]{2}{*}{$\begin{array}{l}\text { (of which } \\
\text { Baluchistan) }\end{array}$} & & & & & $(3.87)$ & (3\%) \\
\hline & 73.6 & 79.6 & 90.0 & 104.5 & 117.35 & \\
\hline $\begin{array}{l}\text { Downstream } \\
\text { Kotri }\end{array}$ & 68.6 & 1.9 & 5.1 & 15.8 & To be det & nined \\
\hline
\end{tabular}

Source: 1 "Report of land and Water Development in the Indus Plain "The Revelle Report. White House, 1964 pp. 69.

2 "Pakistan Statistical Year book 2009" Government of Pakistan pp. 67.

${ }^{3}$ Indus Water Accord 1990-91 in Pakistan Water Economy Running Dry. IBRD 2005, p.20. The Accord protects Punjab on the basis of historical use (1977-82) in case of shortages below 117.35 (MAF).

In addition to the need for water storage to provide a regular supply of water downstream Kotri in order to preserve the Indus Basin Delta, the seasonality of the Indus system rivers' flows (with more than $80 \%$ of the water flowing in the kharif season (largely in June-August) also requires the storage of summer flows so that an adequate winter crop is cultivable. As Table-2 below indicates, in good river flow years, virtually the entire existing storage capacity at Mangla and Tarbela (13.5 MAF in 1998/99, about $12 \mathrm{MAF}$ in 2007/08) can be used, while in drought years, about 40$50 \%$ of the storage capacity can be used to carry water into the next crop. 
Table-2: Seasonality in the Indus River System (Million acre feet)

\begin{tabular}{crrrrrr}
\hline & $\mathbf{1 9 9 8 - 9 9}$ & \multicolumn{2}{c}{$\mathbf{2 0 0 1 - 0 2}$} & \multicolumn{2}{c}{$\mathbf{2 0 0 7 - 0 8}$} \\
\hline Actual Flow Western Rivers $^{1}$ & & & & & & \\
Kharif & 124.97 & $(84 \%)$ & 79.88 & $(82 \%)$ & 105.89 & $(84 \%)$ \\
Rabi & 24.56 & $(16 \%)$ & 17.29 & $(18 \%)$ & 20.19 & $(16 \%)$ \\
& 149.53 & & 97.17 & & 126.08 & \\
Actual Flows Eastern Rivers & 12.26 & & 1.38 & & 1.25 & \\
Canal Withdrawals & & & & & & \\
$\quad$ Kharif & 72.79 & $(66 \%)$ & 58.11 & $(73 \%)$ & 74.45 & $(71 \%)$ \\
Rabi & 37.91 & $(34 \%)$ & 21.50 & $(27 \%)$ & 30.08 & $(29 \%)$ \\
& 110.70 & & 79.61 & & 104.53 & \\
Downstream Kotri & 35.15 & & 1.93 & & 15.80 & \\
\hline
\end{tabular}

${ }^{1}$ Actual Flows at Rim Stations - Indus at Tarbela, Jhelum at Mangla, Chenab at Marala for Western Rivers only.

Source: Pakistan Statistical Year book 2009, pp. 66, 67.

\section{Salinity Current Situation Analysis.}

The water logging and salinity problems of the Indus System irrigation areas stem from its geography. The Indus Plain is essentially flat, rising gradually at a rate of about 1 foot per mile from the sea in the south to the Kalar Kahar Range in the north near Islamabad. Lahore at a height of 700 feet is 700 miles from Karachi. The generally level ground allows canal irrigation but it also means that salts will leach into the soil from the Indus rivers' water that contain salts brought down from the mountains where the rivers originate. In addition, both southern Punjab and Sindh were originally deserts and the present alluvial surfaces of these lands were created by river floods which themselves contained salts. ${ }^{16}$ Thus both the irrigation waters and the soils themselves contains salts, and when the water table rises to about 10 feet underground, the capillary action of the soil forces the salt-impregnated underground water to the root zone of the crops, damaging plant growth and even killing the plant. As mentioned earlier, at the time of the Revelle Report (1964), while only about $30 \%$ of the Indus Basin was affected by water logging and salinity, another $30 \%$ had water at least 10 feet near the surface. Revelle, et al. (1964) anticipated that the salinity problem would ultimately affect almost $70-80 \%$ of the Indus Basin, hence the report's ambitious basin-wide proposed projects. Revelle's SCARPs and their subsequent successors - private

\footnotetext{
${ }^{16}$ Revelle, op. cit. pp. 56.
} 
tube-wells - have largely reversed the problem and today, while there is still a salinity problem because of the nature of the irrigation system and now subsequently through secondary tube-well water-induced salinity, it appears to be more containable. Presently, it is estimated that about 5.4 million acres (of the total of 48.7 million acres under cultivation in the Indus Basin) or about $11 \%$ is affected by primary or secondary salinization. ${ }^{17}$ One third of the affected area is in Punjab and the remaining in Sindh. In Punjab, salinity is due to both canal water and tube-well irrigation, but the major problem now is secondary or tube-well-related salinity. In Sindh, the problem is overwhelmingly canal water-related salinity since the water aquifer is largely saline and tube-well use is relatively limited. Table-3 below summarizes the situation with regard to Indus Basin salt balances. A noteworthy feature is that, in aggregate, the Indus Basin's salt balances retained in the root zone appear to be in balance and may be marginally deceasing. ${ }^{18}$ In addition in Sindh, the LBOD has been remarkably successful and together with the new RBOD may actually allow successful management of salt levels in the area.

Table-3: Indus Basin Salt Balances

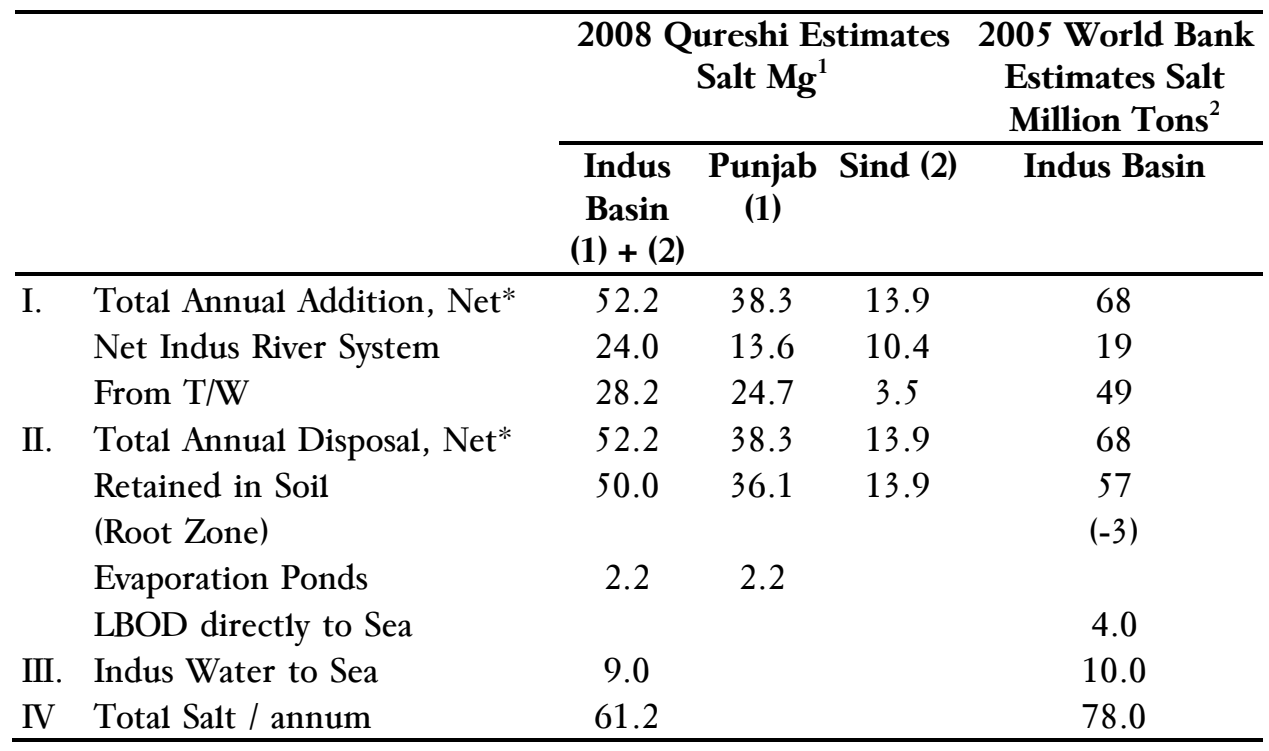

*Excluding $9 \mathrm{Mg}$ annual salt flow washed out to Sea (Qureshi etc.) or 10 million tons annual salt flow washed out to sea (World Bank).

Sources: "Managing salinity and water logging in the Indus Basin of Pakistan," Qureshi A.S. et. A1. Agriculture Water Management 95 (2008), pp. 4.

2“Pakistan Water Economy Running Dry,” World Bank 2005, pp. 48.

17 "Managing salinity and water logging in the Indus Basin of Pakistan," Qureshi, A.S et al, Agriculture Water Management Journal, (2008) pp. 3.

18 “Pakistan: Water Economy Running Dry ,” op. cit. pp. 48. 
Groundwater Current Situation Analysis.

The increasing use of groundwater extracted through small private tube-wells has changed the nature of the IBIS. Encouraged initially by the example of the massive number of SCARP-imported tube-wells which, as Revelle, et al. (1964) anticipated, added dozens of MAF to the irrigation system, Pakistan's private farmers used local electricians to fabricate small tube-wells running both on electrical and diesel power. This in large part freed farmers from the water shortage experienced in the rabi season and enabled them to balance the system at times of canal closure. In addition, it enabled them to plant more water-intensive crops such as rice in the kharif season by using tube-wells to augment the already plentiful supply of irrigation water in this season (a time when water tables are already high because of monsoon rains). Finally, and most importantly, it enabled Pakistani farmers to counter the approximately 3-5 year drought cycle of the Indus River system (discussed later). There were costs to underground water both in terms of additional salinity (discussed earlier) and the decline in water table levels. However, the overuse of groundwater was mitigated at least to some extent because (unlike India) electricity and diesel for tube-wells was not subsidized. Qureshi (2009) points out that the average cost of tube-well water is about 30 times that of canal water or roughly US\$5.5/hectare/year for canal water as compared to US\$167/hectare/year for tube-wells. ${ }^{19}$ However, as Table4 below shows, groundwater extracted through tube-wells amounted to about $50 \mathrm{MAF}$ in $2007 / 08$ of which about $40 \mathrm{MAF}$ was from private tube-wells, 7.8 MAF from SCARPs, and 1.73 MAF from public tube-wells. As a result, aquifers are being slowly depleted in Pakistan's Indus Basin (although not as dramatically as in Indian Punjab; this is discussed 1ater). Currently, $80 \%$ of Punjab's aquifer recharge is from the irrigation system. ${ }^{20}$ The balance is largely from monsoon rainfall and return flow from groundwater. It is estimated that the groundwater level has dropped to inaccessible depths in 5\% of Punjab (a sign of groundwater depletion) and this is expected to decline to $15 \%$ in the next decade. ${ }^{21}$ This implies that, at current rates, Pakistani Punjab aquifers will be completely depleted in 50-100 years. Groundwater prospects are discussed in detail later.

\footnotetext{
19 "Challenges and Prospects of Sustainable Ground Water Management in the Indus Basin, Pakistan,” Qureshi A.S. et al. Water Resources Management Journal, Springer, 2009.

${ }^{20}$ Pakistan Water Economy Running Dry. op. cit. pp. 15.

21 "Challenges and Prospects of Sustainable Ground Water........" op. cit. pp. 7.
} 
Table-4: Pakistan Overall Water Availability (2007-08) (Million Acre Feet)

\begin{tabular}{|c|c|c|c|c|c|c|}
\hline \multirow[b]{2}{*}{ 2007-08 } & \multicolumn{2}{|c|}{ Surface Water } & \multicolumn{2}{|c|}{ Ground Water } & \multirow[b]{2}{*}{$\begin{array}{c}\text { (4) } \\
\text { Public } \\
\text { T/W } \\
\end{array}$} & \multirow{2}{*}{$\begin{array}{c}(1+2+3+4) \\
\text { Total } \\
\text { Water } \\
\text { Availability } \\
\end{array}$} \\
\hline & $\begin{array}{c}\text { at Canal } \\
\text { Head }\end{array}$ & $\begin{array}{c}\mathbf{( 1 )} \\
\text { At Farm } \\
\text { Gate } \\
\end{array}$ & $\begin{array}{c}(2) \\
\text { Private } \\
\mathbf{T} / \mathbf{W} \\
\end{array}$ & $\begin{array}{c}(3) \\
\text { SCARP } \\
\text { T/W } \\
\end{array}$ & & \\
\hline Kharif & 70.78 & 61.12 & 19.70 & 3.90 & 0.86 & 85.58 \\
\hline Rabi & 27.94 & 31.40 & 20.68 & 3.91 & 0.87 & 56.86 \\
\hline Total & 98.72 & 92.52 & 40.38 & 7.81 & 1.73 & 142.44 \\
\hline
\end{tabular}

Source: Pakistan Statistical Year Book 2009, pp. 64.

\section{An IBIS Strategy for the Next Decades: The Supply Side}

Any analysis of a future IBIS strategy must necessarily begin with the supply side since absolute initial constraints-the flows of the Indus system's three western rivers-limit the total availability of surface water in Pakistan. Secondary constraints relate to the absolute size of groundwater aquifers where more than $80 \%$ of the recharge is by the same western rivers. Within these constraints there is annual flexibility in the surface water system determined by storage capacity in dams and multi-year flexibility in the groundwater system with the aquifers acting as huge underground dams. However, before discussing these supply-side constraints and mitigation measures, it is important to examine the Indus Water Accord (IWA) with India and its future prospects.

\section{IWA 1960. Future Prospects.}

As discussed earlier, the total flow of the entire Indus Water System (the Indus plus its tributaries) is about $180 \mathrm{MAF}$, which was divided by the IWA by giving the Indus, Jhelum, and Chenab (150 MAF) to Pakistan and the Ravi, Sutlej, and Beas (30 MAF) to India. However, the IWA gave certain rights to India over the western rivers including limited agricultural use (70,000 acres from the Indus, 400,000 acres from the Jhelum, and 225,000 acres from the Chenab-a total of 695,000 acres). The IWA also gave India the right to construct runoff river hydroelectric plants with limited pondage and dead storage. ${ }^{22}$ As legally written and if properly enforced, Pakistan would lose only a maximum of 3 to $4 \mathrm{MAF}$ from its western rivers, which would be in conformity with the IWA.

\footnotetext{
${ }^{22}$ Indus Water Accord 1960, Annexure C and D, Government of Pakistan.
} 
However, in practice, major problems are beginning to average as a result of the construction of new hydro-projects by India. The first of these, Baglihar, completed in 2009 was questioned by Pakistan in that it had live gated storage. This was challenged by Pakistan before the World Bank (the guarantor of the IWA); the World Bank with the agreement of both India and Pakistan appointed a "neutral expert" as laid down in the IWA. Unfortunately the neutral expert "reinterpreted" the treaty to allow limited live storage to allow the flushing out of silt, and this permission allowed India to cause immense damage to Pakistan by completing and filling the Baglihar Dam on the Chenab during the rabi season in 2009/10 when Pakistan received almost no water from the Chenab. ${ }^{23}$ John Briscoe, the World Bank Irrigation Advisor at that time and the person responsible for selecting the neutral expert, is now Professor of Environmental Engineering at Harvard and has stated recently that "if Baglihar was the only dam being constructed on the Chenab and Jhelum this would be a limited problem. But following Baglihar is a veritable caravan of Indian ProjectsKishanganga, Sawalkat, Pukuldul, Bursar, Dal Huste, Gyspa .... The cumulative live storage will be large, giving India an unquestionable capacity to have major impact on timing of flows into Pakistan." ${ }^{24}$

This situation is further complicated by the fact that the Indian Punjab's much vaunted "agricultural miracle" is running out of groundwater. A recent authoritative academic study on Indian Punjab's groundwater points out that the Indian Punjab's agriculture is overwhelmingly dependant on groundwater which is becoming rapidly depleted. The study states: "The total surface availability at different head works is about 1.80 hectare meter (Mha-m) per annum (Government of Punjab 2005). Out of this 0.35 Mha-m per annum is lost during conveyance and only 1.45 Mha-m is available at the outlet that irrigates about 1.0 Mha land. The total sustainable availability of ground water is $1.68 \mathrm{Mha}-\mathrm{m}$ annum. The current crop production pattern dominated by paddy wheat crop rotation requires 4.37 Mha-m of irrigation water per annum, against the total supply of 3.13 Mha$\mathrm{m}$ per annum from both surface and annual recharge of groundwater resources, leading to a net deficit of 1.24 Mha-m (Government of Punjab 2005). Consequently the deficit is being met by over exploitation of the groundwater resources. This has played havoc with the groundwater resources of the State." ${ }^{25}$ The Columbia Water Centre (the Earth Institute at

\footnotetext{
23 “War or Peace on the Indus?” Briscoe, John, The News, April 3, 2010 pp. 6.

${ }^{24}$ Briscoe, John,. op. cit.

25 "Concerns of Groundwater Depletion and Irrigation: Efficiency in Punjab Agriculture - A Micro-Level Study,” .Jeevendas A., Singh RP., and Rumer, B. Agriculture Economics Research Review, Vol. 21, July-December 2008, pp. 195.
} 
Columbia University) in a recent concept note on water security in Indian Punjab states that "In 1985 less than $5 \%$ of tube wells were sustainable. By 2005 that number had increased to over $60 \%$. If these trends of aquifer depletion continue, it is estimated that Punjab's groundwater will be entirely exhausted in 15-20 years. $^{26}$

India is developing the capacity to violate the IWA and has the need for Pakistan's waters as shown above. It is, therefore, imperative that the "Office of the Commissioner Indus Water Accord" within the Ministry of Water, Government of Pakistan be strengthened and a dialogue with India undertaken to ensure that India does not violate the IWA in letter or spirit. In the meantime, Pakistan should anticipate at a minimum that India will use to the full its allowable water use on the western rivers according to the IWA. This will mean a minimum withdrawal of about 5 MAF of water in both flood, normal, and drought years. Thus, if 1998 is considered a flood year with 111 MAF of canal withdrawals, 2007/08 is considered a normal year with 105 MAF withdrawals, and 2001/02 is considered a drought year with $80 \mathrm{MAF}$ of withdrawals, this use of water by India under the IWA would mean a reduction in the Indus system's canal water availability of western rivers' waters to $105 \mathrm{MAF}$ annually in flood years, about $100 \mathrm{MAF}$ in normal years, and about $75 \mathrm{MAF}$ in drought years.

Indus River Seasonality, Drought and Climate Change:

The Requirement for New Storage Dams on the Indus.

As shown earlier in this paper, the Indus River system exhibits seasonality within the year with $80 \%$ of its flows occurring in the kharif season when the glaciers melt in the summer in Kashmir (the Western Himalayas). This necessitates having live storage capabilities. A further complicating factor that also requires live storage for mitigation is that the Indus River also seems to have a " 3 to 5 year flood and drought cycle" as Figure 1 below indicates.

26 "Concept Note on Water Security in Punjab, India Current Scenario.” /Water Columbia /edu/..../India. Website dated April 9, 2010. 


\section{Figure-1: Western Rivers: Inflow at Rim Stations}

Million Acre Feet (MAF)

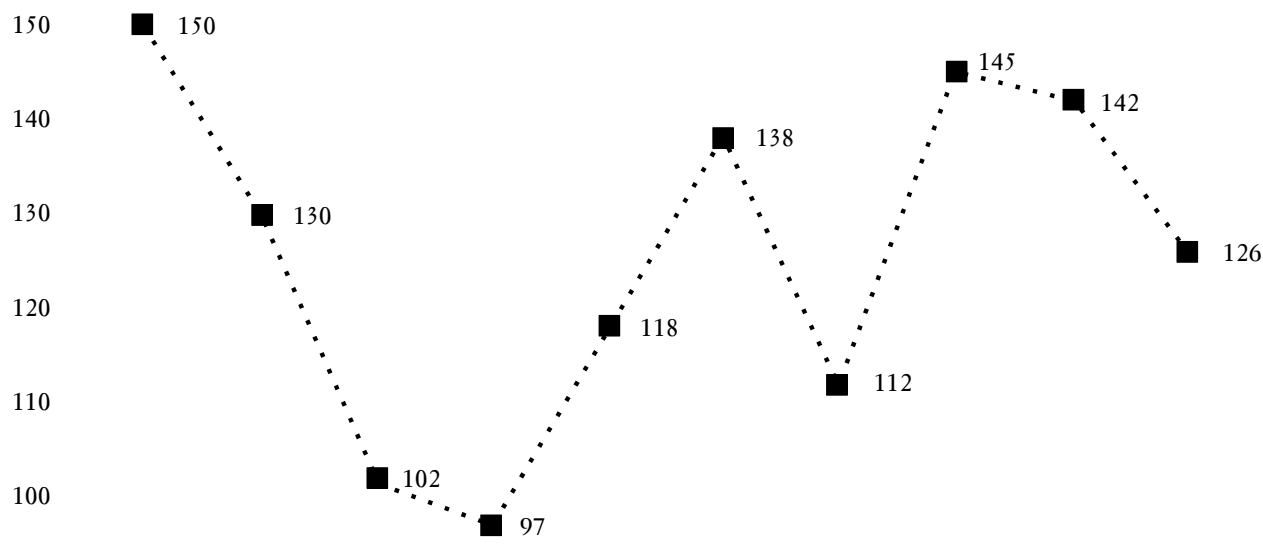

90

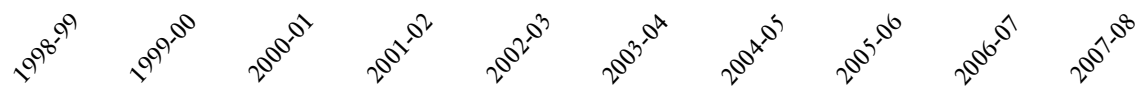

Source: Pakistan Statistical Year Book 2009, pp. 66.

In addition to the "flood followed by drought cycle" illustrated above, Pakistan faces the prospects of climate change. Current forecasts (despite their uncertain nature) show the Western Himalayan glaciers melting in the next 50 years which will mean initially massive river flows followed by meltdown and consequent 30 to $40 \%$ decreases in river flows. This climate change will be accompanied by increased rainfall which will accentuate flooding problems of the rivers in the first 50 years and subsequently mitigate the low flows in the rivers in the next 50 years. ${ }^{27}$ This is a daunting prospect and needs to be managed.

Overall, the implications of the latter three IBIS supply side situations (viz., the kharif-rabi imbalance, the multi-year imbalance, and the climate change imbalance) all require the construction of additional storage on the Indus River. Excluding climate change, requirements for normal Indus River imbalances can be determined on the basis of "yield curves." The Lieftinck Report (1967) calculated a yield curve for storage capacity on the Indus shown in Table- 5 below. This seems to indicate that Pakistan optimally requires about 22 MAF of storage on the Indus while the present storage capacity is about $8 \mathrm{MAF}$ at Tarbela and an additional 6 MAF if Basha is constructed as planned. Thus, an additional storage or two after Basha will be required on the Indus to deal with the present

27 “Pakistan Water Economy Running Dry,” IBRD 2005 op. cit. pp. 25. 
situation. The climate change requirement for storage on the Indus will have to be determined after further analysis. The Asian Development Bank has indicated that it will support the construction of Basha on which preconstruction activities (roads, colonies, etc.) have been started by WAPDA and which will cost about $\$ 8$ billion over the period 2010-2016. The World Bank is still shying away from investing further in Pakistan's water resource development as indicated earlier, but has recently shown interest in a hydro-electric project at Dasu (downstream Basha, upstream Tarbela). The storage capacity at Dasu has not yet been established and it is not yet clear whether this is an optimal second large new storage dam site. However, if a second storage on the Indus is constructed with a further capacity of $6 \mathrm{MAF}$, this (together with Basha) should add another 12 MAF of usable canal head availability to the Indus River system in flood and normal years, and about 6 MAF of additional capacity to the system in drought years. Again, applying the same numbers of Indus River system availability and use by India according to the IWA, Pakistan after constructing this additional storage of $12 \mathrm{MAF}$ will have available usable canal head availability of about 117 MAF per annum in flood years, 112 MAF in normal years, and about 87 MAF in drought years.

Table-5: Storage Yield Curve for River Indus

\begin{tabular}{lccccc}
\hline Storage MAF & 10 & 15 & 20 & 25 & 30 \\
Additional Yield in MAF/Yr & 10 & 15 & 20 & 22 & 22.5 \\
\hline
\end{tabular}

Source: Numerical data above estimated from Yield Curve for River Indus presented In Pakistan: Water Resources Running Dry 2005, IBRD, p.xiii based on "Study of Water Resources of West Pakistan” (The Lieftinck Report), IBRD 1967.

Yield curves for the Jhelum River are not available. However, the Jhelum River with its average flows of 15-23 MAF/ annum (compared to the Indus's average flows of 70-100 MAF/annum) currently has about 9 MAF of storage capacity as a result of the recent raising of the Mangla Dam by an additional 30 feet which increased its storage capacity by 2.9 MAF to the 6 MAF of storage capacity already existing. This capacity now appears adequate for managing current Jhelum River inter-year and multi-year imbalances. However, additional capacity may have to be added to meet the requirements of climate change. Similarly, while yield curves are not available for the Chenab River and there are no mountainous natural storage sites on the plains where the Chenab enters Pakistan, climate change requirements may require in-line and off-line storage in the future (on/off the rivers and canals). 
Ground Water Supply Side Prospects.

As discussed earlier, Pakistan's groundwater aquifers are diminishing-although not at the furious pace of Indian Punjab. It is imperative that Pakistan's groundwater aquifers be stabilized (i.e., tube-well withdrawals be equivalent to aquifer recharging by irrigation water leaching, rainfall etc.) Table-6 below presents some estimates (dated almost 10 years) which show that IBIS aquifers were generally in balance during normal years, with about $9 \mathrm{MAF} / \mathrm{annum}$ of depletion in drought years with this depletion being confined entirely to Punjab. This situation must inevitably have worsened in the last decade. Qureshi (2009) estimates that groundwater was inaccessible through small tube-wells (operable at less than $20 \mathrm{~m}$ water depth) in $5 \%$ of Punjab in 2000 and that this figure was expected to increase to $15 \%$ in the next decade. ${ }^{28}$ Given this situation, it is clear that Pakistan and particularly Punjab cannot count on any further increase in groundwater extraction. Regulatory controls have been legislated but it has not proved possible to enforce them. Energy pricing policies with no real subsidy on agricultural tube-wells and the fact that $85 \%$ of tubewells run on market-price diesel has naturally dampened tube-well demand as compared to Indian Punjab where electricity for tube-wells is free. Pakistan will need to watch its aquifers carefully and take corrective measures if tube-well extraction soars above current levels. On the supply side, however, it needs to be recognized that additions to water supply for irrigation from groundwater in the IBIS is not practicable and even minor subsidies, if any, on agriculture tube-well electricity should be withdrawn as soon as possible.

28 "Challenges and Prospects of Sustainable Groundwater Management in the Indus Basin Pakistan,” Qureshi et al, op.cit. 
Table-6: IBIS Aquifer Balances 2001-02 (MAF)

\begin{tabular}{|c|c|c|c|c|c|c|}
\hline & $\begin{array}{l}\text { Punjab } \\
\text { Normal } \\
\end{array}$ & $\begin{array}{c}\text { Punjab } \\
\text { Drought }\end{array}$ & $\begin{array}{c}\text { Sind } \\
\text { Normal } \\
\end{array}$ & $\begin{array}{l}\text { NWFP } \\
\text { Normal }\end{array}$ & $\begin{array}{c}\text { IBIS } \\
\text { Normal } \\
\end{array}$ & $\begin{array}{c}\text { IBIS } \\
\text { Drought }\end{array}$ \\
\hline Aquifer Balance & 0 & -8.6 & 0 & -0.4 & -0.4 & -9.0 \\
\hline $\begin{array}{l}\text { Tube wells } \\
\text { Abstractions }\end{array}$ & -30.8 & -33.6 & -3.5 & -1.8 & -36.1 & -38.9 \\
\hline $\begin{array}{l}\text { Base Flow to } \\
\text { Rivers/Subsurfaces }\end{array}$ & -2.5 & -0.4 & -1.2 & -1.4 & -5.1 & -3.0 \\
\hline $\begin{array}{l}\text { Evapo - } \\
\text { Transportation Losses }\end{array}$ & -1.6 & -0.8 & -13.8 & -0.2 & -15.6 & -14.8 \\
\hline $\begin{array}{l}\text { Recharge from } \\
\text { Irrigation System }\end{array}$ & 20.6 & 15.5 & 15.4 & 1.9 & 37.9 & 32.8 \\
\hline Recharge from Rivers & 3.2 & 0.8 & 0.3 & 0.1 & 3.6 & 1.2 \\
\hline $\begin{array}{l}\text { Return flow from } \\
\text { groundwater }\end{array}$ & 4.6 & 5.1 & 0.8 & 0.1 & 5.5 & 6.0 \\
\hline $\begin{array}{l}\text { Recharge from } \\
\text { Rainfall }\end{array}$ & 6.5 & 4.8 & 2.0 & 0.9 & 9.4 & 7.7 \\
\hline
\end{tabular}

Source: "Water Sector Issues with a Focus on Groundwater Management: A Policy Perspective, "Qureshi S.K. and Hirashima S. in Problems and Politics of Water sharing and Management in Pakistan, Cheema et. al. Editors, Islamabad Policy Research Institute, 2007.

Increasing Water Supply through Reducing Irrigation Water Transmission Losses.

IBIS surface water transmission losses are substantial-25\% or a normal $25 \mathrm{MAF}$ in the canal system alone. ${ }^{29}$ There is another substantial loss in water course transmissions and there are further losses in field application. However, as Table-6 (above) indicates, the IBIS depends in normal years on about 38 MAF of groundwater recharge from the irrigation system. The only savings that are possible are in saline water areas. In Punjab poor water quality is found in $23 \%$ of the area and this number rises to $78 \%$ for Sindh. ${ }^{30}$ The lining of canals in saline groundwater areas in Sindh and the saline areas of Punjab is likely to make about 5 MAF of additional irrigation water available in Sind and about 5 MAF additional in Punjab. The WAPDA Chairman has recently stated that WAPDA was studying the possibility of lining the Rohri, Dadu, and Rice

\footnotetext{
29 “Issues in Water Policy Reforms,” Masood Ahmed, op. cit, pp. 79.

30 "Sustainable Groundwater Management in the Indus Basin, Pakistan,” Qureshi et. al. op. cit.
} 
canals in Sindh, and if this was undertaken it would allow an additional 492,000 acres of land to be brought under irrigation in Sind. ${ }^{31}$ Another area of savings lies in the lining and rehabilitation of water channels. The Planning Commission estimated that 90,000 water courses (out of a total of 135,000 country-wide) could be improved by lining, rehabilitation, etc., thereby saving about $6 \mathrm{MAF}{ }^{32}$ Total Indus water system farm gate availability cumulatively after adding these water transmission loss savings and savings from additional surface storage and abstracting from Indian IWA uses is therefore likely to be almost $133 \mathrm{MAF}$ in flood years, $128 \mathrm{MAF}$ in normal years, and $103 \mathrm{MAF}$ in drought years.

\section{IBIS Demand Management Prospects.}

\section{Future Requirements of Agriculture Crops.}

Pakistan is already a great agricultural country producing about 24 million tons of wheat, 7 million tons of rice, 3.6 million tons of maize, 50 million tons of sugarcane, 12 million tons of vegetables, and 7 million tons of fruits in 2008/09, in addition to an assortment of other crops. ${ }^{33}$ The country's cultivated area extended over 52 million acres in 2008/09 (of which 90\% is part of the IBIS) and crop production was fairly mechanized with all ploughing done by tractors and a sizeable percentage of wheat and rice crops mechanically harvested. Pakistan itself produced about 65,000 tractors per annum. ${ }^{34}$ However, yields are low by international standards and particularly in comparison with Indian Punjab. Thus, recent wheat yields are estimated by the World Bank to be 7 tons/ha or 130 mds/acre in Imperial Valley, USA, 3.8 tons/ha or $62 \mathrm{mds} / \mathrm{acre}$ in Bhakra, India, and 1.8 tons/ha or $31 \mathrm{mds} / \mathrm{acre}$ in Punjab, Pakistan. The conclusion drawn by the World Bank is that "attention will have to shift from productivity per unit of land to productivity per unit of water." 35 This is an interesting distinction but not very useful in practice since yield/acre may be significantly different because of the use of high yielding varieties of seed, higher use of fertilizers, etc., while still using the same quantities of water. Data from a recent study that examines irrigation water use in Haryana (India) and Punjab (Pakistan) has estimated water use for wheat in Haryana at 2,200 $\mathrm{m}^{3} /$ hectare and in Punjab at $2,500 \mathrm{~m}^{3} /$ hectare, while for paddy, the estimated water use was $18,900 \mathrm{~m}^{3} /$ hectare for Haryana and 16,000

\footnotetext{
31 “WAPDA Reviving Irrigation Network,” Durrani, S. Dawn, April 15, 2010, pp. 15.

${ }^{32}$ Ten Year Perspective Plan 2001-11, Planning Commission 2001, pp. 283-288.

${ }^{33}$ Agricultural Statistics of Pakistan, 2008-9, p (xi).

${ }^{34}$ Pakistan Statistical Yearbook 2009, pp. 2, 64.

35 “Pakistan: Water Economy Running Dry 2005,” IBRD, pp. 30.
} 
$\mathrm{m}^{3} /$ hectare for Punjab (Table-7). ${ }^{36}$ Specifically, Pakistan's Punjab uses water $12 \%$ less efficiently than India for wheat production and is $18 \%$ more efficient in water use for rice production using the traditional definition of water use per acre. However, both Indian Haryana's and Indian Punjab's wheat and rice productivity is higher than that of Pakistan's Punjab.

Table-7: Comparison of Haryana India and Punjab Pakistan (Per Hectare)

\begin{tabular}{lcc}
\hline & $\begin{array}{c}\text { Haryana } \\
\text { India }\end{array}$ & $\begin{array}{c}\text { Punjab } \\
\text { Pakistan }\end{array}$ \\
\hline Wheat & 246 & 174 \\
Total nutrients $\left(\left[\mathrm{kg} \mathrm{N}+\mathrm{P}_{2} \mathrm{O}_{5}+\mathrm{K}_{2} \mathrm{O}\right]\right) \mathrm{ha}^{-1}$ & 2.2 & 2.5 \\
Estimated irrigation water use ('000 $\left.\mathrm{m}^{3} \mathrm{ha}^{-1}\right)$ & 4.2 & 3.2 \\
Grain yield (ton ha $\left.{ }^{-1}\right)$ & & \\
Rice & 209 & 139 \\
Total nutrients $\left(\left[\mathrm{kg} \mathrm{N}+\mathrm{P}_{2} \mathrm{O}_{5}+\mathrm{K}_{2} \mathrm{O}\right]\right) \mathrm{ha}^{-1}$ & 18.9 & 16.0 \\
Estimated irrigation water use $\left({ }^{-1} 000 \mathrm{~m}^{3} \mathrm{ha}^{-1}\right)$ & 4.6 & 3.6 \\
Paddy yield (ton ha $\left.{ }^{-1}\right)$ &
\end{tabular}

Source: "Comparing water management in rice-wheat production systems in Haryana, India and Punjab Pakistan”, Erenstein, Olaf, Agriculture Water Management 96, 2009, p.1803.

The particularly striking difference in average crop productivity between Indian Punjab and Pakistan's Punjab is sometimes argued in part to be due to the availability of free electricity for tube-wells, which, it is estimated, saves the Indian Punjab farmer about $\$ 162 /$ hectare/year for solely tube-well irrigated land as compared to solely canal irrigated land ${ }^{37}$ or about Rs 7,000/acre/year for each combined crop cycle of wheat plus rice. This saving, it is argued, is used by the Indian Punjab's farmers to purchase additional fertilizer, pesticides, mechanical land-leveling, mechanical planting, and mechanical harvesting, which contributes to doubling the yield in Indian Punjab as compared to Pakistan's Punjab. This may well be the case. In addition, the Indian Punjab farmer may also have access to

\footnotetext{
36 “Comparing Water Management in Rice-Wheat Production Systems in Haryana, India and Punjab Pakistan,” Erenstein, O., Agriculture Water Management 96, 2009, pp.1803.

37 "Challenges and Proposals of Sustainable Groundwater Management in the Indus Basin,” Qureshi et. al. op. cit.
} 
cheaper fertilizer, more advanced seeds, and a guaranteed and efficient procurement system. However, it is important to learn from the Indian Punjab's experience in increasing yields. This includes using better land and crop management practices. It has also been estimated that the single most important factor in the efficient use of water in Pakistan's Punjab may be land-leveling-resulting in savings of as much as $20-30 \%$ compared to unleveled land. ${ }^{38}$ Finally, Pakistan should seriously consider shifting away from water-intensive crops such as rice to alternative efficient water-use crops such as vegetable oils (sunflowers, soya bean), maize, and more cotton.

Future IBIS strategy for meeting addition crop/food requirements over the next decades will therefore require the following: (i) doubling or tripling yields by improving land practices and greater use of hybrid seeds, fertilizers and pesticides; (ii) using water, both surface and ground water, resources more efficiently, preferably by reducing average surface water requirements for crops through land leveling etc. and reducing, if possible, ground water use. A shift in kharif away from rice to more efficient crops is also required. Total water use in terms of canal withdrawals for crop production should be "frozen" at present "normal year" uses, i.e. about 105 MAF and groundwater withdrawals in IBIS should also be "frozen" at present levels of about 50 MAF.

\section{Environmental Use of IBIS System Waters.}

A source of contention since the IWA has been the fact that, in drought years, there is almost no water downstream of Kotri, causing immense damage to the Indus Delta. In order to get agreement on the 1990 Inter Provincial Accord, this issue was deliberately left unaddressed to be determined later by "expert studies." Subsequently, studies were commissioned which came up with the following findings: (i) downstream Kotri requirements and recommended associated environmental flows from the Indus were estimated at 3.60 MAF in dry or average years with $25 \mathrm{MAF}$ additional every five years in times of flood, or alternatively, 8.60 MAF as an average for all years to be provided from the overall share; ${ }^{39}$ (ii) the recommended environmental flow allocation for the Indus, Chenab, Ravi, Sutlej, and Jhelum to maintain a minimum water depth of 0.5 to 1 meter were 8.25 MAF to be provided from the overall share; (iii) recommended environmental flows allocation for Punjab's lakes, water bodies, and riverine

\footnotetext{
38 "Water Saving Technologies: Myths and Realities Revealed in Pakistan's Rice Wheat Systems,” Ahmad, M.D, et. al., IWMI Research Report 108, 2007, Colombo, Sri Lanka.

${ }^{39}$ Study on Water Escapes Below Kotri to Check Sea Water Intrusion. Final Report. Montgomery Watson Harza et. al., Ministry of Water and Power, Federal Flood Commission, 2005, pp. 56.
} 
areas, etc., were 6.22 MAF to be provided from Punjab's share; (iv) recommended environmental flows allocation for Sindh's lakes, water bodies, and riverine areas, etc., were 2.53 MAF to be provided from Sindh's share. ${ }^{40}$ Table- 8 below summarizes the expert consultants' recommendations.

Table-8: IBIS Environmental Flow Requirements

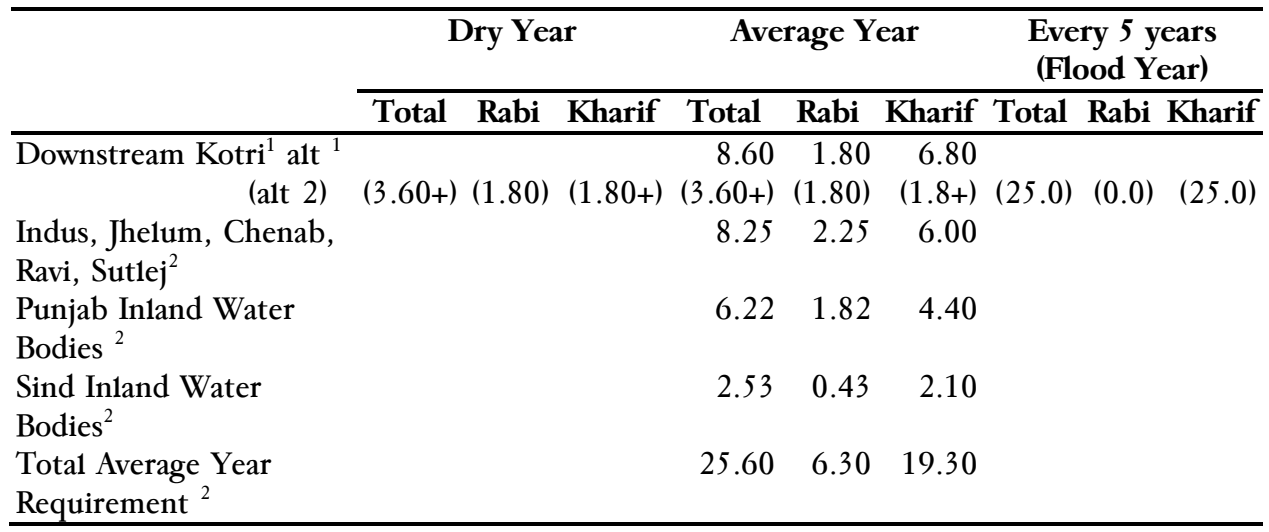

Source: 1 "Study on Water Escapes Below Kotri". 2005, op. cit. p.57.

2 "Environmental Concerns of all Four Provinces, 2005, op.cit. p.1.

The recommendations for the use of net additional water from IBIS storage augmentation (12 MAF), lining of canals (10 MAF), and improvement of water courses (6 MAF), or a total of $28 \mathrm{MAF}$ for the next few decades flow almost naturally from the above. In flood years: (i) the equivalent of additional water to be made available from the new storage at Basha on the Indus plus a large portion of the flood should be used to meet downstream Kotri requirements; (ii) part of the additional flood water plus equivalent additional water to the second storage dam on the Indus (Dasu) should be used to meet the environmental requirements of the Indus, Jhelum, Chenab, Ravi, and Sutlej; (iii) the equivalent of the additional waters to be saved from the lining of canals and water courses in Punjab and Sindh together with part of the flood waters should be used for reviving the wetlands of Punjab and Sindh. In normal years, half the additional water from additional storage and lining of canal in saltwater areas and water course rehabilitation should be used for irrigation flows and the other half for environmental flows (particularly downstream Kotri). In drought years, three quarters of this additional water should be used to augment irrigation water supplies and the remaining amount for environmental flows (again, with special

${ }^{40}$ Environmental Concerns of all the Four Provinces: Solutions. Executive Summary, AAB, DHV, ITC, DE, LFT Hydraulics, Ministry of Water and Power, Federal Flood Commission, 2005, pp. 1-8. 
attention to downstream Kotri). It is not clear whether Pakistan is politically and economically ready to make such an environmental commitment to its IBIS waters. Yet this will have to be done, whether by this or subsequent generations, for Pakistan needs to make its rivers, wetlands, and delta alive again so that Pakistan can revert to being the land of the "Five Rivers" with inland navigation (ultimately) from the Indus Delta to the banks of all the five rivers as was historically the case.

\section{Efficiency in the use of IBIS and Ground Water.}

If additional water to be made available from the IBIS is recommended for use in substantial part to meet drought and environmental requirements, then the question arises as to how Pakistan will expand its irrigated areas, particularly in northern Punjab (Thal), southern Punjab (Bahawalpur/Cholistan), Sindh (eastern and western banks), and Balochistan. The sensible answer would be to put a restriction on adding any new command areas to the IBIS. Such a restriction is likely to be unenforceable. Therefore, the many important technologies currently available to preserve water, including precision land-leveling, zero tillage, bed and furrow planting, and drip irrigation together with the adoption of high yielding varieties of genetically modified crops (particularly in maize and cotton) will be useful in both saving water and expanding irrigated areas. The only note of caution that needs to be made is that the current drive by international institutions (particularly the World Bank) to reform the institutional arrangements surrounding the IBIS system is well intentioned but should be handled with sense. The newly created provincial irrigation department authorities (PIDAs) proposed by the World Bank is a good idea especially if it enables these replacements of provincial irrigation departments to retain irrigation revenues (currently these go directly to the provincial government accounts) to be used to rehabilitate the provincial irrigation systems. The creation of farmers' organizations (which now cover $20 \%$ of the irrigation areas in the IBIS) also proposed by the World Bank to monitor water supplies from the distributaries (the sequence is rivers to branch canals to main canals to distributaries) to the khalas (watercourses) which each command about 500 acres is also a welcome initiative and has led to improved supplies to tail-enders and some controls over water theft. Farmers also need to pay more for their canal waters to control waste in water use and also to maintain and augment the IBIS. They also need to be not charged if they do not use their assigned water entitlements. However, the current elaborate system of irrigation entitlements throughout the IBIS (i.e., 20 minutes/acre/week for field crops, double for fruit orchards) through a defined capacity and regulated outlet that is uniformly administered should not be touched at any cost since this is the bedrock of 
the system. No attempt should be made to charge the "full opportunity cost of water" or privatize the system as is the current long-term thrust of the World Bank's recommendations. However, cost recovery for adequate maintenance of the irrigation system by the provincial governments is essential and "abiana" or water rates need to be increased to cover these requirements. Large-scale capital investments in the irrigation system will have to be financed by the federal government although it is tempting to think of some cost recovery from investments in the federal government (WAPDA)-owned and operated storages.

\section{Conclusions on Future IBIS Strategy}

The analysis presented above indicates that Pakistan has come a long way in its development of the IBIS. The first two decades, 1950-1970, were occupied by the urgent need to "re-plumb" the entire system by connecting the western river to the eastern rivers to meet the consequences of Pakistan's requirements under the IWA. The next two decades (1970-90) with an overlap between 1965 and 1970 were used primarily to stem the menace of water logging and salinity. The decade 1990-2000 was the "lost decade"-focused on institutional issues which are important but were used as a means to stop major investments by the public sector in the IBIS. The last decade (2000-2010) has been the first where Pakistan has been able to build and modernize the IBIS and this is expected to be followed by several decades of further enhancement of the system. As the system is modernized, however, it is imperative that Pakistan focus on: (i) creating additional surface storage to offset both intra-year variations in the Indus River system and its three- to five-year flood and drought cycle; (ii) surface water preservation particularly by lining canals in saline areas and watercourse improvement; (iii) groundwater conservation and salinity control by discouraging excessive tube-well use; (iv) encouraging general efficiency of irrigation water use through improved land management techniques including land-leveling and also by changing the kharif cropping pattern away from water-intensive rice to sunflower, soya, maize, and more cotton; (v) yield enhancement through improved farming practices, adopting hybrid seeds, and increased fertilizer and pesticide use; and (vi) fully meeting the environmental concerns of the Indus Delta, river systems, and wetlands. This, together with a clear vision that the IBIS will be publically owned and operated but with sensible institutional reform (including the increased price of canal waters) which would increase water use efficiency without destabilizing the entire system of existing irrigation entitlements, is the recommended strategy for the future. 


\section{References}

Ahmad, M.D, Turra1, H., Masih, I., Giordano, M. and Masood, Z., (2007). Water Saving Technologies: Myths and Realities Revealed in Pakistan's Rice Wheat Systems, IWMI Research Report 108, Colombo, Sri Lanka.

Ahmed, M. (1999). Issues in Water Policy Reforms, The Politics of Managing Water. Edited by Bengali K, Oxford University Press.

Briscoe, J. (2010). War or Peace on the Indus. The News. April 3, 2010.

Durrani, S. (2010). Wapda Reviving Irrigation Network, Dawn, April 15, 2010 .

Earth Institute, Columbia University (2010). Concept Note on Water Security in Punjab, India Current Scenario, /Water Columbia /edu/..../India.

Erenstein, O. (2009). Comparing Water Management in Rice Wheat Production Systems in Haryana, India and Punjab Pakistan, Agriculture Water Management, 96.

Federal Flood Commission (2005). Environmental Concerns of all the Four Provinces: Solutions, Executive Summary.

Government of Pakistan (1960). Indus Water Accord (1960).

Government of Pakistan (2009). Pakistan Statistical Year Book.

Government of Pakistan. (2009). Agricultural Statistics of Pakistan (200809).

IBRD (2005). Pakistan Water Economy Running Dry.

Jeevendas A., Singh R.P., and Rumer, B. (2008). Concerns of Groundwater Depletion and Irrigation: Efficiency in Punjab Agriculture - A MicroLevel Study, Agriculture Economics Research Review, 21.

Kazi, A. (1999). Analysis of Water Accords in Politics of Managing Water. Oxford University Press. 
Lieftinck Report, IBRD (1967). Study of the Water Resources of West Pakistan, II.

Montgomery Watson Harza et a1. (2005). Study on Water Escapes below Kotri to Check Sea Water Intrusion. Final Report, Federal Flood Commission.

Planning Commission, Government of Pakistan, (2001). Ten Year Perspective Plan 2001-11.

Planning Commission, Government of Pakistan. (2002). Annual Review (2001-2) of the Ten year Perspective Plan 2001-11 and Three Year Development Program 2002-05.

Qureshi A.S et al, (2009). Challenges and Prospects of Sustainable Ground Water Management in the Indus Basin, Pakistan. Water Resources Management Journal.

Qureshi A.S. et al. (2008). Managing Salinity and Water Logging in Pakistan. Agriculture Water Management Journal.

Qureshi S.K. and Hirashima S. (2007). Water Sector Issues with a Focus on Groundwater Management: A Policy Perspective in Problems and Politics of Water Sharing and Management in Pakistan. Islamabad Policy Research Institute.

Revelle, H., Falcon et a1. (1964). Report on Land and Water Development in the Indus Plain. The White House.

WAPDA (2004). Water Resources and Hydro-Power Development Vision 2025 . 